\title{
Sociobiology
}

SHORT NOTE

\section{Primitively Eusocial Behavior Observed in Colonies of Augochlora amphitrite (Hymenoptera: Halictidae) Reared in Laboratory}

\author{
M DALMAZZO ${ }^{1,2}$, A ROIG-ALSINA ${ }^{1}$ \\ 1 - Museo Argentino de Ciencias Naturales “Bernardino Rivadavia” CONICET, Ciudad Autónoma de Buenos Aires, Argentina \\ 2 - Universidad Nacional del Litoral, CONICET, Santa Fe, Argentina
}

\section{Article History}

\section{Edited by}

Cândida Aguiar, UEFS, Brazil

Eduardo Almeida, USP, Brazil

Received 15 May 2018

Initial acceptance 16 July 2018

Final acceptance 26 August 2018

Publication date $\quad 11$ october 2018

\section{Keywords}

Artificial nests, social interactions, wild bees, Augochlorini.

\section{Corresponding author}

Milagros Dalmazzo

Cátedra de Entomología

Departamento de Ciencias Naturales

Facultad de Humanidades y Ciencias

Universidad Nacional del Litoral CONICET

Ciudad Universitaria Paraje El Pozo

CP: 3000, Provincia de Santa Fe, Argentina.

E-Mail: milidalmazzo@yahoo.com

\begin{abstract}
The present study provides evidence of primitively eusocial behavior in Augochlora amphitrite (Schrottky). Bees were reared in laboratory nests and observed throughout their nesting cycle. Introduced foundresses constructed nests solitarily, but upon the emergence of the first daughter their activities changed drastically, marking the onset of a social phase. The colonies presented two well defined female castes according to their physiology, size and behavior. Foundresses monopolized oviposition, displayed low rates of nest construction, guarding, and pollen collection, they were the individuals that initiated social interactions, and were statistically larger. Daughter bees were smaller, with undeveloped ovaries, performed most tasks at the nest and were the subordinate individuals in social interactions.
\end{abstract}

Augochlora Smith is a New World genus of halictid bees with a wide distribution, ranging from southern Canada to the Pampean Region in Argentina, where five species occur (Dalmazzo \& Roig-Alsina, 2011). Two subgenera are recognized, Oxystoglossella Eickwort, which includes soil-dwelling, social species, and Augochlora s.str. species, which nest in decaying wood (Michener, 2007). Species of the latter were considered solitary, based on limited data obtained from nests in the field (Eickwort \& Eickwort, 1973; Zillikens et al., 2001) and from laboratory study of the solitary species Augochlora pura (Say) (Stockhammer, 1966). The existence of eusocial behavior in this subgenus was surmised from studies of nests of Augochlora isthmii Schwarz and Augochlora amphitrite (Schrottky) in the field (Wcislo et al., 2003; Dalmazzo \& Roig-Alsina, 2012) and recently confirmed, based on the study of artificial nests of Augochlora phoemonoe (Schrottky) (Dalmazzo \& Roig-Alsina,
2015). These findings suggest that eusocial behavior could be more frequent in the subgenus, and that solitary forms could be derived from eusocial ancestral behavior. More data on different species are needed to test this hypothesis in a phylogenetic framework. This study analyzes the social behavior observed in three colonies of $A$. amphitrite reared in artificial nests maintained in laboratory conditions.

Twenty-nine adult females foraging on flowers were collected in the surroundings of Buenos Aires during spring (October - November) of 2008 and 2009, marked on the scutum with different colors of nail polish, and introduced into a flight room. They were placed into small holes in the substrate of the artificial nest (Fig 1; for detailed description of artificial nests and flight-room construction, see Dalmazzo, 2018). Five females succeeded establishing active nests and produced at least one brood. Two females produced only males. Daughter females were marked with a two-color code on the scutum: 
one color indicated to which nest a female belonged (same color as her mother), and the other one allowed to discriminate between daughters of the same nest. Nests were observed daily from the introduction of foundresses until dissection of the nests at the end of the season (March). Each observation session took place between 8:00 and 20:00, totaling an average of 45 hours per nest. During each observation session, each nest was watched by the same observer continuously for $20 \mathrm{~min}$. The order in which the nests were observed was randomly assigned each day to avoid observation biases. Focal sampling was used to trace the behavior of individuals; the number of times (frequency counts) that each individual performed each activity or interaction from the behavioral catalogue was recorded on nests that contained daughter females. The behavioral catalogue is the same as the catalog detailed for A. phoemonoe (Dalmazzo \& Roig-Alsina, 2015). The life cycle of $A$. amphitrite in the laboratory nests was characterized by a solitary phase in which the five introduced foundresses constructed a main tunnel and 1 to 3 clustered cells. These females foraged in the flight room, provisioned and laid eggs in the cells, and also guarded the nest entrances. This phase lasted an average of $32( \pm 2.05)$ days. The developmental time of emerged females varied between 30 and 35 days $(\mathrm{N}=7$, median $=32)$ and that of emerged males varied between 28 and 31 days $(\mathrm{N}=9$, median $=30)$. The activities of the foundresses changed drastically upon the emergence of the first daughter, marking the onset of the social phase (Table 1). Two nests had three emerged daughters and one had a single daughter, the remaining two nests produced only males and their foundresses had unfertilized spermathecae. One daughter female emerged from one of these nests with 3 daughters, dispersed, and founded her own nest producing only males. Nest productivity ranged from 2 to 6 individuals (adults and pupa stages), with an average of $4.33 \pm 1.7(\mathrm{~N}=3)$. The cells produced $2 \pm 0.82$ (mean $\pm \mathrm{SD}$ ) of males, which emerged in February - March. Emerged males stayed within the nest for $12-20$ hours and did not participate in any activity. At the time of dissection of the nests by the end of March, one individual (male) was still at the stage of pupa. We found statistical differences (Mann-Whitney U test) between frequencies of activities performed by foundresses $(\mathrm{N}=3)$ and daughters $(\mathrm{N}=6)$ during the social phase (Table 1). Daughter females had higher frequencies of construction and pollen collecting. Guarding was mostly performed by daughters during the social phase ( $\mathrm{p}$ value $=0.07$, close to 0.05). On the other hand, interactions, such as passing, antennation-tarsation and following, were mostly initiated by foundresses, and oviposition was exclusively performed by them (Table 1 indicates statistical differences).

The bees were dissected at the end of the nest cycle and classified according to their ovarian development (groups A to $\mathrm{C}$, from ovaries well developed to not developed) and wear of wings and mandibles (in a scale from 0 to 3, intact to much worn) (Dalmazzo \& Roig-Alsina, 2012). Foundresses

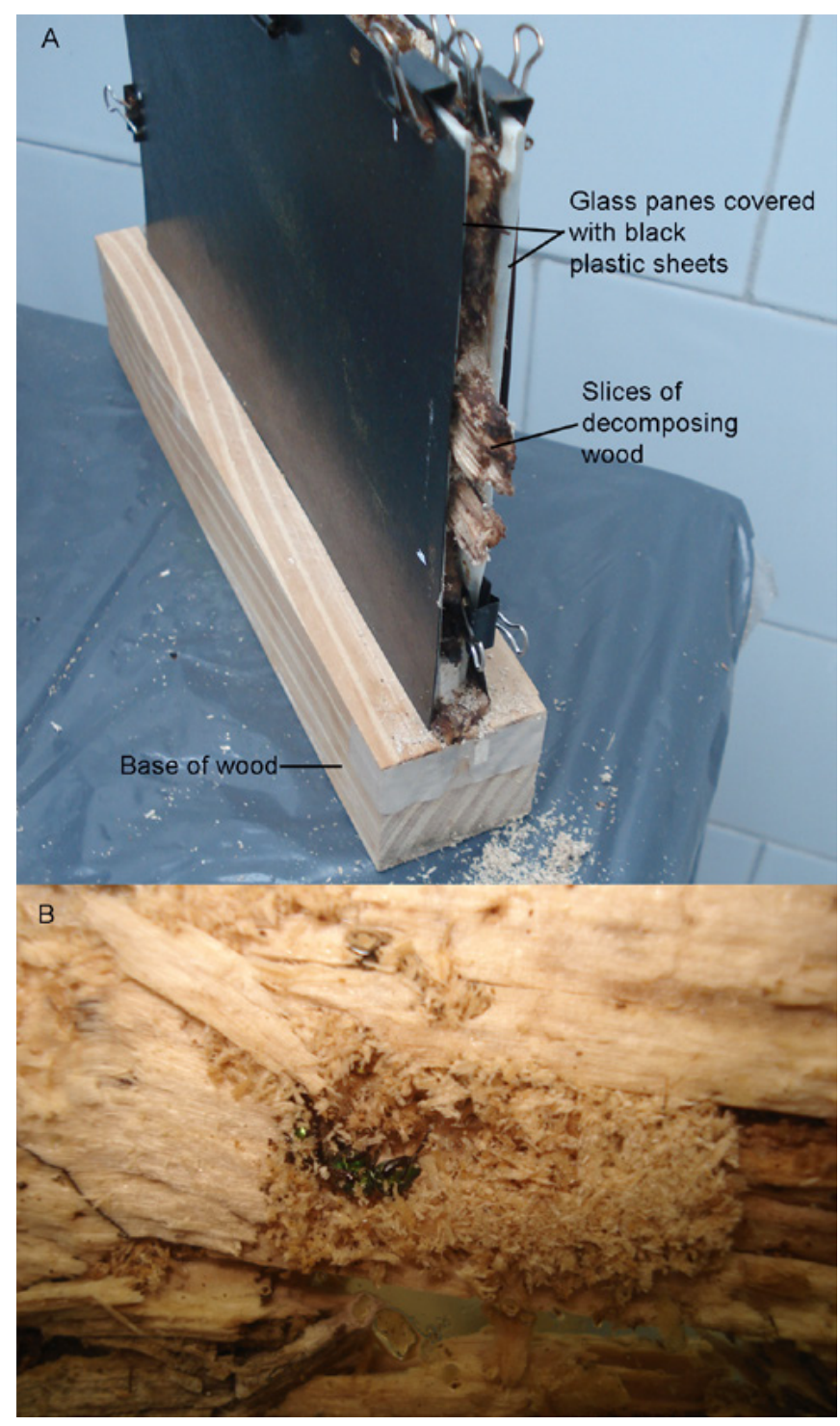

Fig 1. A- Artificial nest where the colonies of Augochlora amphitrite were reared; B- daughter female and sawdust from cell construction between the glass panes of the artificial nest.

were characterized by well developed ovaries (groups A and B; $\mathrm{N}=3$ ) and worn wings (classes 2 and 3; $\mathrm{N}=3$ ) and mandibles (class $3 \mathrm{~N}=3$ ), while daughter bees had slender ovaries (group $\mathrm{C} ; \mathrm{N}=6$ ) and less worn wings (classes 1 and $2 ; \mathrm{N}=6$ ) and mandibles (classes 1 and $2 ; \mathrm{N}=6$ ). The mean values of length of body (LB) and length of forewing (LF) were significantly larger in foundresses $(\mathrm{LB}=11.33 \pm 0.94 ; \mathrm{LF}=5.48 \pm 0.14$ $\mathrm{mm})$ than in daughter bees $(\mathrm{LB}=8.46 \pm 1.2 ; \mathrm{LF}=4.99 \pm 0.34$ mm Wilcoxon test, $\mathrm{p}=0.03$ ).

The only species of Augochlora s. str. for which primitively eusocial behavior is well documented is $A$. phoemonoe (Dalmazzo \& Roig-Alsina, 2015). As in this species, we found in A. amphitrite two well defined castes according to their physiology, size and behavior. Foundresses monopolize oviposition, and display low rates of nest construction, guarding, and pollen collection during the social phase (Table 1); they are the individuals that initiate 
social interactions. Daughter bees have undeveloped ovaries, perform most tasks at the nest and are the subordinate individuals in social interactions. Castes are morphologically alike, except that mean size of foundresses was higher than mean size of daughter bees. Sub-castes, such as guards or foragers (Michener, 1990) were not identified. Most daughter females stay in the nest helping in the production of a new generation, but one of them was able to initiate her own nest. Disperser females are known in social species of the tribe Halictini (Michener, 1990), as well as in two species of Augochlorini: Augochlorella striata (Provancher) (Mueller, 1996) and Augochloropsis iris (Schrottky) (Coelho, 2002), which are primitively eusocial. The present study provides evidence of primitively eusocial behavior (Michener, 1990) in A. amphitrite, involving cooperative brood care among motherdaughter assemblages, wherein the foundress monopolizes oviposition and the daughters perform most of the tasks at the nest, and castes are differentiated by size only.

Table 1. Activities and interactions performed by foundresses and daughters observed in three nests of Augochlora amphitrite. Median frequencies and standard deviation (SD) are presented for each type of activity and interaction. Bold values indicate statistical significant differences between foundresses and daughters during the social phase (U: Mann-Whitney $U$ test, $\mathrm{p} \leq 0.05$ ).

\begin{tabular}{|c|c|c|c|c|c|}
\hline & \multicolumn{2}{|c|}{ Foundresses $(N=3)$} & \multirow[t]{2}{*}{ Daughters $(N=6)$} & \multirow[t]{2}{*}{$\boldsymbol{U}$} & \multirow[t]{2}{*}{$p$} \\
\hline & Solitary phase & Social phase & & & \\
\hline \multicolumn{6}{|c|}{ Locomotion } \\
\hline Mean \pm SD & $21 \pm 7.74$ & $44.33 \pm 3.05$ & $50.86 \pm 21.45$ & 4.5 & 0.17 \\
\hline \multicolumn{6}{|l|}{ Feeding } \\
\hline Mean \pm SD & $7.33 \pm 4.93$ & $12.67 \pm 1.53$ & $19 \pm 11.40$ & 8 & 0.57 \\
\hline \multicolumn{6}{|c|}{ Construction } \\
\hline Mean \pm SD & $18 \pm 8.72$ & $3 \pm 2.64$ & $20.57 \pm 15.46$ & 2 & 0.05 \\
\hline \multicolumn{6}{|c|}{ Pollen collecting } \\
\hline Mean \pm SD & $6.67 \pm 1.15$ & $\mathbf{0}$ & $8.14 \pm 6.47$ & 1.5 & 0.03 \\
\hline \multicolumn{6}{|l|}{ Guarding } \\
\hline Mean \pm SD & $7 \pm 2.64$ & $3.33 \pm 2.08$ & $22 \pm 15.90$ & 2.5 & 0.07 \\
\hline \multicolumn{6}{|l|}{ Oviposition } \\
\hline Mean \pm SD & $1.67 \pm 1.15$ & $2 \pm 1$ & $\mathbf{0}$ & $<0.001$ & 0.003 \\
\hline \multicolumn{6}{|c|}{ Sudden retreat } \\
\hline Mean \pm SD & 0 & $20.33 \pm 7.50$ & $0.86 \pm 1.07$ & $<0.001$ & 0.01 \\
\hline \multicolumn{6}{|c|}{ Antennation-tarsation } \\
\hline Mean \pm SD & 0 & $31 \pm 8.54$ & $2.28 \pm 1.60$ & $<0.001$ & 0.02 \\
\hline \multicolumn{6}{|l|}{ Passing } \\
\hline Mean \pm SD & 0 & $18.33 \pm 1.53$ & $1 \pm 0.58$ & $<0.001$ & 0.01 \\
\hline \multicolumn{6}{|l|}{ Following } \\
\hline Mean \pm SD & 0 & $12.33 \pm 6.03$ & $0.57 \pm 1.13$ & $<0.001$ & 0.01 \\
\hline
\end{tabular}

\section{Acknowledgements}

We thank Eduardo Almeida and two anonymous reviewers for their comments on the manuscript. This study was supported by grants ANPCyT, Argentina, 2007-1238, and CONICET, Argentina, PIP 2011-0288.

\section{References}

Coelho, B.W.T. (2002). The biology of the primitively eusocial Augochloropsis iris (Schrottky, 1902). Insectes Sociaux, 49: 181-190.

Dalmazzo, M. (2018). Biología de nidificación de la abeja eusocial primitiva Augochlora phoemonoe (Halictidae). Revista del Museo Argentino de Ciencias Naturales, nueva serie, 20: 1-10.
Dalmazzo, M. \& Roig-Alsina, A. (2011). Revision of the species of the New World genus Augochlora (Hymenoptera, Halictidae) occurring in the southern temperate areas of its range. Zootaxa, 2750: 15-32.

Dalmazzo, M. \& Roig-Alsina, A. (2012). Nest structure and notes on the social behavior of Augochlora amphitrite (Schrottky) (Hymenoptera, Halictidae). Journal of Hymenoptera Research, 26: 17-29. doi: 10.3897/JHR.26.2440

Dalmazzo, M. \& Roig Alsina A. (2015). Social biology of Augochlora (Augochlora) phoemonoe (Hymenoptera, Halictidae) reared in laboratory nests. Insectes Sociaux, 62: 315-323. doi: 10.1007/s00040-015-0412-8

Eickwort, G.C. \& Eickwort, K.R. (1973). Notes on the nests of three wood-dwelling species of Augochlora from Costa 
Rica (Hymenoptera: Halictidae). Journal of the Kansas Entomological Society, 46: 17-22.

Michener, C.D. (1990). Reproduction and castes in social Halictine bees. In W. Engels (Ed.), Social Insects: An Evolutionary Approach to Castes and Reproduction (pp. 77121). Berlin Heiderbelrg-New York: Springer.

Michener, C.D. (2007) The bees of the world. 2nd Ed. Baltimore: Johns Hopkins University Press.

Mueller, U.G. (1996). Life history and social evolution of the primitively eusocial bee Augochlorella striata. Journal of the Kansas Entomological Society, 69: 116-138.

Stockhammer, K.A. (1966). Nesting habit and life cycle of a sweet bee, Augochlora pura. Journal of the Kansas Entomological Society, 39: 157-192.
Wcislo, W.T., Gonzalez, V.H. \& Engel, M.S. (2003). Nesting and social behavior of a wood-dwelling Neotropical bee, Augochlora isthmii (Schwarz), and notes on a new species, $A$. alexanderi Engel (Hymenoptera: Halictidae). Journal of the Kansas Entomological Society, 76: 588-602.

Zillikens, A., Steiner, J. \& Mihako, Z. (2001). Nest of Augochlora (A.) esox in bromeliads, a previously unknown site for sweat bees (Hymenoptera: Halictidae). Studies on Neotropical Fauna and Environment, 36: 137-142. doi: 10.1076/ snfe.36.2.137.2133

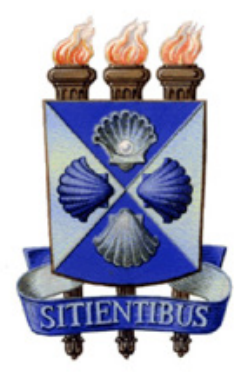

